\title{
Modifikasi Alat Pemintal Benang Sutera Untuk Industri Rumah Tangga
}

\author{
Abdul Salam ${ }^{1 *}$, Muh. Iswar ${ }^{2}$, Bensar Pali $^{3}$, Agustinus Anggai ${ }^{3}$, Janchristo Rantemangnga $^{5}$ \\ 1,2,3,4,5 Jurusan Teknik Mesin, Politeknik Negeri Ujung Pandang, Makassar 90245, Indonesia \\ *abdsalam@poliupg.ac.id
}

\begin{abstract}
This study aims to determine the yarn spinning time, spinning equipment manufacturing costs, and haspel shaft spinning. Basic design is done by data collection, direct visits to the silk farmers' groups, tool design, tool manufacturing, performance testing tools, analysis, calculating costs and tool manufacturing. In accordance with the testing of the spinning machine, the total working time is 8 hours / day for $3.36 \mathrm{~kg}$ of silk yarn, the spinning equipment manufacturing cost is Rp. 5,102,534.71. Whereas BEP is achieved when the sale of spinning machines is at least 1 unit / month or when income is Rp. 5,621,064.
\end{abstract}

Keywords: yarn spinner; haspel; manufacturing costs

\begin{abstract}
Abstrak: Penelitian ini bertujuan untuk menentukan waktu pemintalan benang, biaya manufaktur alat pemintal, dan putaran poros haspel. Dasar perancangan dilakukan dengan pengumpulan data, kunjungan langsung ke kelompok tani sutera, perancangan alat, pembuatan alat, pengujian kinerja alat, analisa, menghitung biaya dan pembuatan alat. Sesuai dengan pengujian alat pemintal yang dilakukan diperoleh total waktu kerja 8 jam/hari untuk sebanyak 3,36 kg benang sutera, biaya manufaktur alat pemintal sebesar Rp. 5.102.534,71. Sedangkan BEP tercapai saat penjualan alat pemintal minimal 1 unit/bulan atau saat penghasilan diperoleh Rp. 5.621.064.
\end{abstract}

Kata kunci : pemintal benang; haspel; biaya manufaktur

\section{PENDAHULUAN (Font 11, capslock)}

Di Sulawesi Selatan terdapat beberapa kabupaten sebagai sentra penghasil benang sutera dan tenunan sutera seperti Kab. Soppeng, Wajo, Bone, Enrekang, dan Mandar. Kabupaten Soppeng merupakan daerah yang potensil dan menjadi pemasok benang sutera untuk beberapa daerah yang ada di Provinsi Sulawesi Selatan. Menurut [1] areal pertanaman murbei Kab. Soppeng sangat luas, demikian pula aktivitas persuteraan seperti pemeliharaan ulat sutera, pemintalan benang, hingga pertenunan. Jumlah produksi benang per tahunnya sebesar 18.053 ton yang diproduksi dari 387 unit pemintal. Namun demikian, masalah terbesar yang dihadapi industri kecil persuteraan lokal adalah produksi benang sutera yang masih sangat terbatas, belum dapat memenuhi permintaan pasar. Produsen tekstil sutera terpaksa harus mengimpor benang sutera asal China meskipun harganya cukup mahal. Harga benang sutera impor China berkisar Rp.280.000-Rp.330.000/kg. sedangkan benang sutera lokal sekitar Rp. 150.000-Rp 200.000/kg [2]. Berdasarkan hasil survei yang dilakukan dan studi pendahuluan tim peneliti [3], menunjukkan bahwa masalah yang paling urgen bagi pengembangan usaha kecil menengah persuteraan di Kabupaten Soppeng adalah masih rendahnya produktivitas yang disebabkan efisiensi dan efektivitas mesin yang digunakan. Alat pemintal benang sutera yang ada sekarang terdiri atas dua macam yaitu alat tradisional (manual) dan mesin bantuan pemerintah pada tahun 2005, sementara untuk alat penggulung benang sutera masih menggunakan alat tradisional yang terbuat dari kayu dan diputar secara manual. Mesin pemintal bantuan Pemerintah, sudah tidak dioperasikan lagi karena rusak dan tidak mudah mendapatkan suku cadangnya di pasaran. Mesin pemintal tersebut masih memiliki kekurangan, yaitu jika ada salah satu benang yang putus pada teromol (haspel), maka operasi mesin harus dihentikan untuk menyambung. Usaha persuteraan di daerah tingkat II Kab. Soppeng sangat potensial untuk dikembangkan karena merupakan salah satu komoditas unggulan daerah tersebut, namun demikian permasalahan yang ada saat ini adalah produktivitas benang sutera masih sangat rendah karena efektivitas dan efisiensi alat/mesin yang 
digunakan belum optimal. Areal tanaman murbei yang begitu besar merupakan potensi alam yang tak ternilai harganya untuk menunjang komoditas unggulan daerah dalam hal usaha persuteraan alam. Di sisi lain, pengelolaan sutera khususnya bagi usaha industri kecil menengah masih terkendala dengan penggunaan alat yang kurang efisien dan efektif dalam menghasilkan benang sutera, sehingga secara keseluruhan produktivitas benang sutera belum dapat ditingkatkan secara maksimal. Alat pemintal benang sutera yang terbanyak digunakan terbuat dari kayu dengan konstruksi yang cukup besar dan digerakkan secara manual. Hal ini menyebabkan proses pemintalan benang sutera menjadi tidak optimal dan membutuhkan beban kerja yang besar. Selain itu, konstruksi alat yang terbuat dari kayu kurang presisi mengakibatkan mekanisme gerakan tidak stabil, sehingga benang sutera yang dipintal sering putus. Mesin pemintal bantuan pemerintah pada tahun 2005 yang sudah tidak digunakan lagi memiliki kekurangan dalam pengoperasiannya.

\section{METODE PENELITIAN}

Sutera adalah serat yang diperoleh dari serangga Lepidoptera. Serat sutera berbentuk filament, dihasilkan oleh larva ulat sutera pada saat membentuk kepompong. Sutra atau sutera merupakan serat protein alami yang dapat ditenun menjadi tekstil. Jenis sutra yang paling umum adalah sutra dari kepompong yang dihasilkan larva ulat sutra murbei (Bombyx mori) yang diternak (peternakan ulat itu disebut serikultur).

Dalam penelitian ini penentuan daya motor menggunakan persamaan [4]:

$$
\mathrm{P}=\frac{\text { Fs.Vs }}{4500}
$$

Dimana: $\mathrm{P}=$ daya motor (hp); Fs = gaya $(\mathrm{kg}) ; \mathrm{Vs}=$ kecepatan $\mathrm{radial}(\mathrm{m} / \mathrm{menit})$

Poros digunakan sebagai penerus daya yang akan mentranmisikan torsi dari motor dengan puli sabuk.Tegangan puntir yang terjadi pada poros dihitung dengan menggunakan persamaan:

$$
\tau p=\frac{M p}{W p}
$$

Dimana: $\not p=$ Tegangan punter $\left(\mathrm{N} / \mathrm{mm}^{2}\right) ; \mathrm{Mp}=$ Momen punter $(\mathrm{Nmm}) ; \mathrm{Wp}=$ Momen tahanan puntir $\left(\mathrm{mm}^{3}\right)$.

Sabuk merupakan alat transmisi daya dan putaran pada poros yang berjauhan posisinya. Sistem transmisi sabuk yang digunakan pada penelitian ini adalah sabuk bulat yang dipasang pada puli dengan alur V. Menurut Sularso dan Kiyokatsu Suga[4], panjang sabuk diketahui dengan persamaan:

$$
L=\left[\pi\left(r_{1}+r_{2}\right)+2 X+\frac{\left(r_{1}-r_{2}\right)^{2}}{X}\right]
$$

Dimana: $\mathrm{r}_{1}=$ jari-jari puli poros transmisi $(\mathrm{mm}) ; \mathrm{r}_{2}=$ jari-jari motor $(\mathrm{mm}) ; \mathrm{X}=$ jarak sumbu poros transmisi ke sumbu poros motor $(\mathrm{mm})$.

Pada perencanaan ini, baut yang digunakan untuk mengikat adalah jenis baut tembus. untuk mengetahui besar tegangan geser dapat digunakan persamaan:

$$
\tau g=\frac{4 \mathrm{~F}}{\pi \cdot \mathrm{d}^{2} \cdot \mathrm{r}} .
$$

Dimana: $\tau g=$ tegangan geser $\left(\mathrm{N} / \mathrm{mm}^{2}\right) ; \mathrm{F}=$ beban $(\mathrm{N}) ; \mathrm{d}=$ diameter baut $(\mathrm{mm}) ; \mathrm{n}=$ jumlah baut

Untuk menentukan diameter puli digunakan persamaan:

$$
\mathrm{D}_{1} \cdot \mathrm{N}_{1}=\mathrm{D}_{2} \cdot \mathrm{N}_{2}
$$

Dimana : $\mathrm{D}_{1}=$ diameter puli motor $(\mathrm{mm}) ; \mathrm{D}_{2}=$ diameter puli poros transmisi $(\mathrm{mm}) ; \mathrm{N}_{1}=$ putaran mesin (rpm); dan $\mathrm{N}_{2}=$ putaran poros transmisi (rpm).

Perhitungan kekuatan sambungan las didasarkan atas luas minimum terhadap beban atau geseran. Luas leher las minimum

$$
\mathrm{A}=\mathrm{h} . \mathrm{L} \text {. }
$$


Sedangkan untuk ukuran tebal las sudut atau las sisi, maka dihitung berdasarkan luas leher las minimum. Menurut Shigley [5], luas leher las minimum adalah:

$$
\mathrm{A}=0,707 \mathrm{~h} . \mathrm{L}
$$

Dimana $: \mathrm{h}=$ Leher las $(\mathrm{mm}) ; \mathrm{L}=$ Panjang efektif las (mm); $\mathrm{A}=$ Luas leher las $\left(\mathrm{mm}^{2}\right)$.

Bantalan adalah komponen yang mampu menumpu poros sehingga putaran dapat berlangsung secara halus, aman, dan panjang umur. Jenis bantalan yang digunakan pada penelitian ini adalah bantalan gelinding, sesuai dengan fungsinya untuk menumpu poros transmisi. Menurut Sularso dan Kiyokatsu Suga, (1983), umur bantalan diketahui dengan persamaan:

$$
\mathrm{Lh}=\frac{L s}{N}=1,67.10^{6} .
$$

Dimana $: \mathrm{Lh}=$ umur bantalan (jam); $\mathrm{n}=$ Putaran poros; $\mathrm{Ls}=$ Umur Bantalan (juta putaran).

Bahan-bahan yang dipergunakan pada pembuatan alat pemintal benang sutera ini antara lain: Plat stainless steel tebal $0.5 \mathrm{~mm}$, Pipa stainless steel Ø 3/4 inch, Pipa PVC Ø 3 inch, Bantalan P 204 (Bearing), Besi holo $4 \mathrm{~cm}$ x $4 \mathrm{~cm}$, Motor listrik, Sabuk, Pulli 2", 3", 4", 6", 8", Baut dan mur, Elektroda las, Poros plastik nilon, Paku keling dan Besi strip 2 × $20 \mathrm{~mm}$. Sedangkan alat-alat/peralatan yang digunakan adalah: Mesin pemotong plat, Mesin bubut, Mesin bending plat, Gergaji besi, Mesin bor tangan, Gergaji besi, Mesin las listrik, Gerinda tangan, Mata gerinda potong, Tang, Mata bor, Meteran 5 m, Palu besi, Mistar ingsut, Ragum, TapM8, Penyiku, Kunci ring-pas 10,12,14, Sikat baja, dan Alat pelindung diri (APD).

Proses rancang bangun pembuatan mesin pemintal benang sutera dilakukan sebagaimana yang diperlihatkan pada Gaambar 1. Langkah awal dari Perancangan yaitu membuat gambar desain konstruksi mesin berdasarkan data-data awal yang diperoleh dari survei lapangan, dan sentra-sentra pembuatan benang sutera di daerah Kabupaten Soppeng. Pembuatan mesin pemintal benang sutera mengikuti beberapa tahapan yaitu: (a) Rangka utama, menggunakan besi holo 4 x $4 \mathrm{~cm}$ dipotong sesuai dengan ukuran, proses penyambungan menggunakan las listrik; (b) Poros, menggunakan pipa stainless steel berdiameter 3/4 inci, yang bagian ujung ditumpu oleh bantalan; (c) Haspel penggulung benang, terbuat dari bahan pipa paralon berdiameter 3 inci; (d) Wadah penampung air panas,

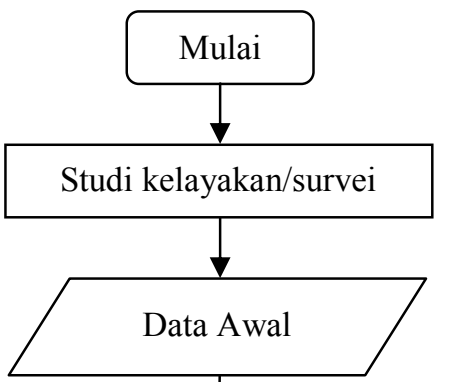


87 Abdul Salam, Muh. Iswar, Bensar Pali, Agustinus Anggai, Janchristo Rantemangnga. Modifikasi Alat Pemintal Benang Sutera Untuk Industri Rumah Tangga

Gambar 1. Alur Pelaksanaan Rancang Bangun Mesin Pemintal Benang

menggunakan bahan pelat stainless steel dengan ketebalan $0,5 \mathrm{~mm}$, yang diletakkan dikedua sisi rangka mesin; (e) Dudukan haspel: menggunakan poros plastik nilon $\varnothing 85 \mathrm{~mm}$ dan dibor $\varnothing 19 \mathrm{~mm}$, kemudian dibuatkan alur; (f) Batang pengarah, terbuat dari besi strip $20 \times 2 \mathrm{~mm}$; (g) Piringan 
pengarah, terbuat dari plat stainless steel $\varnothing 200 \mathrm{~mm}$ dan pipa besi ø $20 \mathrm{~mm}$; (h) Peluncur serat sutera, menggunakan poros plastik nilon $\varnothing 40 \mathrm{~mm}$ dan dibor $\varnothing 6 \mathrm{~mm}$, kemudian dibuatkan alur; (i) Pengarah/ekor babi, terbuat dari kawat besi yang dililit sebanyak dua buah.

Langkah ketiga yaitu Perakitan. Perakitan komponen-komponen meliputi komponen yang dibuat maupun komponen standar yang dibeli. Perakitan tersebut meliputi (1) memasang rangka pada rangka kaki mesin jahit untuk dapat menopang komponen-komponen yang lain, (2) memasang bantalan, (3) memasang poros utama pada bantalan, (4) memasang dudukan haspel/penggulung pada poros utama, (5) memasang piringan pengarah pada poros, (6) memasang pulli pada poros, (7) memasang bak penampungan dan kompor listrik, (8) memasang dan menyetel alat thermo control, (9) memasang motor listrik sabagai alat pengerak pada dudukan motor.

Langkah keempat yaitu Pengujian. Pengujian dilaksanakan untuk memastikan berfungsinya alat sesuai dengan perencaan sebelumnya. Uji coba awal kinerja mesin dengan menempatkan kokon pada tempat/wadah rendaman air panas bersuhu $60^{\circ} \mathrm{C}-100^{\circ} \mathrm{C}$, kemudian menarik bakal benang dari kokon, dimasukkan ke lubang pengarah dan digulung pada haspel penggulung. Selanjutnya mesin pemintal dihidupkkan untuk menggulung serat kokon tersebut sebagai benang sutera. Pengambilan data dilakukan selama 1 (satu) menit pada putaran $630 \mathrm{rpm}, 920 \mathrm{rpm}, 1030 \mathrm{rpm}, 1180 \mathrm{rpm}$ dan $1500 \mathrm{rpm}$.

\section{HASIL DAN PEMBAHASAN}

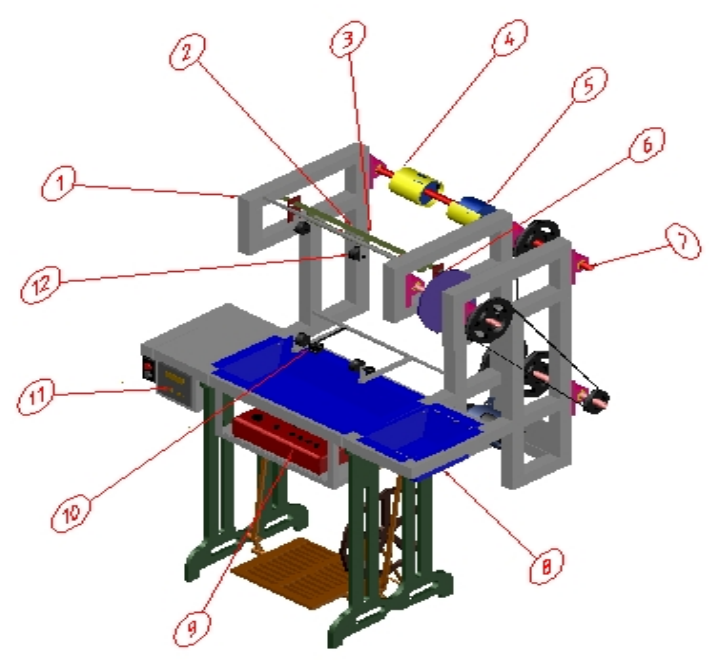

Gambar 2. alat pemintal benang sutera

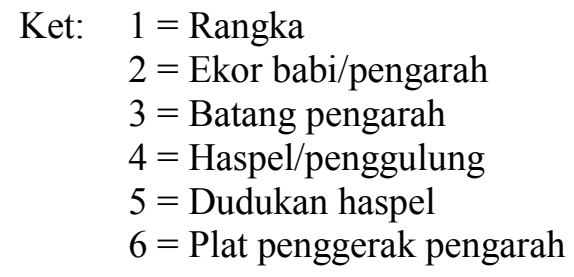

$$
\begin{aligned}
7 & =\text { Poros haspel } \\
8 & =\text { Bak reeling } \\
9 & =\text { Kompor listrik } \\
10 & =\text { Mangkuk } \\
11 & =\text { Thermo control } \\
12 & =\text { Peluncur }
\end{aligned}
$$

Pengujian pemintalan benang sutera dilakukan selama 1 (satu) menit pada 5 jenis putaran yaitu: $630 \mathrm{rpm}, 920 \mathrm{rpm}, 1030 \mathrm{rpm}, 1180 \mathrm{rpm}$ dan $1500 \mathrm{rpm}$. Hal ini dilakukan untuk menentukan jenis putaran yang menghasilkan kapasitas dan kualitas pemintalan yang paling baik. Kokon yang akan dipintal menjadi benang sutera secara kualitas ditentukan berdasarkan (a) jenis kokon yang dipintal dengan baik, dan (b) jumlah kokon yang mengalami putus saat proses pemintalan. Kapasitas produksi didasarkan pada jumlah benang sutera yang dapat digulung per satuan waktu tertentu. Data-data hasil pengujian tersebut dapat dilihat pada tabel 1 . 
89 Abdul Salam, Muh. Iswar, Bensar Pali, Agustinus Anggai, Janchristo Rantemangnga. Modifikasi Alat Pemintal Benang Sutera Untuk Industri Rumah Tangga

Tabel 1 Data hasil pengujian mesin pemintal benang sutera dalam waktu 1 menit

\begin{tabular}{|c|c|c|c|c|c|c|c|}
\hline No. & Percobaan & $\begin{array}{l}\text { Pully } \\
\text { (inch) }\end{array}$ & $\begin{array}{l}\text { Jenis } \\
\text { Kokon }\end{array}$ & $\begin{array}{c}\text { Putaran } \\
\text { (rpm) }\end{array}$ & Hasil (mm) & $\begin{array}{l}\text { Kondisi } \\
\text { benang }\end{array}$ & $\begin{array}{c}\text { Kehalusan } \\
\text { serat }\end{array}$ \\
\hline 1. & I & $\begin{array}{l}8 \rightarrow 6, \\
6 \rightarrow 6\end{array}$ & campuran & 630 & $175.861,98$ & $\begin{array}{l}\text { Tidak } \\
\text { putus }\end{array}$ & halus \\
\hline 2. & II & $\begin{array}{l}8 \rightarrow 6, \\
6 \rightarrow 4\end{array}$ & campuran & 920 & $256.814,32$ & $\begin{array}{l}\text { Tidak } \\
\text { putus }\end{array}$ & halus \\
\hline 3. & III & $\begin{array}{l}8 \rightarrow 6, \\
6 \rightarrow 3\end{array}$ & campuran & 1030 & $287.520,38$ & $\begin{array}{l}\text { Tidak } \\
\text { putus }\end{array}$ & halus \\
\hline 4. & IV & $\begin{array}{l}8 \rightarrow 6, \\
6 \rightarrow 2\end{array}$ & campuran & 1180 & $329.392,28$ & $\begin{array}{l}\text { Tidak } \\
\text { putus }\end{array}$ & halus \\
\hline 5. & V & $\begin{array}{l}8 \rightarrow 3, \\
3 \rightarrow 2\end{array}$ & campuran & 1500 & 418.719 & $\begin{array}{c}\text { Putus } 1 \\
\text { kali }\end{array}$ & $\begin{array}{c}\text { Kurang } \\
\text { halus }\end{array}$ \\
\hline \multicolumn{3}{|c|}{ Rata-rata: } & & 1052 & $293.661,6$ & & \\
\hline
\end{tabular}

Berdasarkan hasil pengujian di atas, maka dipilih putaran yang paling baik yaitu $1180 \mathrm{rpm}$ dengan panjang hasil pintalan benang sutera selama 1 (satu) menit yaitu $329.392,28 \mathrm{~mm}(32,93 \mathrm{~m})$. Pada proses pemintalan tersebut, suhu air pada bak reeling antara $40-70^{\circ} \mathrm{C}$. Hal tersebut menunjukkan bahwa efektivitas dan efisiensi kerja dari proses pemintalan berfungsi dengan baik. Sedangkan saat benang terputus pada saat proses pemintalan berlangsung, dapat diakibatkan oleh putaran mesin, kokon yang akan dipintal, dan suhu air perendaman. Pemintalan benang dapat juga dilakukan secara manual. Keuntungan proses pemintalan secara manual yaitu proses pemintalan tetap berlangsung meskipun tidak ada aliran listrik.

Kekuatan tarik benang saat dipintal menjadi acuan mutu bagi benang tersebut. Benang yang lemah mengganggu proses pemintalan atau pembuatan benang karena sering mengalami putus. Kekuatan tarik benang yang ideal pada umumnya antara 2.001 Newton hingga mencapai 3.499 Newton. Selain itu, beberapa faktor yang mempengaruhi kekuatan benang seperti: panjang staple, kehalusan serat, kekuatan serat, twist, dan kerataan.

\section{KESIMPULAN}

Kesimpulan dari hasil penelitian dijelaskan pada bagian ini

a. Kapasitas produksi alat pemintal benang yang dihasilkan yaitu $3,36 \mathrm{~kg} / 8$ jam kerja. Sebelumnya, hanya $2 \mathrm{~kg} / 8$ jam kerja.

b. Pengoperasian alat pemintal benang sutera dapat dilakukan secara manual, dan menggunakan motor listrik.

c. Biaya manufaktur alat pemintal benang sutera ini sebesar Rp. 5.102.534,71 dengan perkiraan titik pulang pokok (BEP) dicapai bila 1 unit terjual.

\section{DAFTAR PUSTAKA}

[1] Anwar,M. 2011. Bahan Ajar Elemen Mesin II. Makassar: Politeknik Negeri Ujung Pandang.

[2] Dinas Kehutanan Provinsi Sulsel. Data Base Perekonomian Kabupaten Soppeng. 2008.

[3] Salam, Abdul. 2008, Perancangan Alat Penggulung Benang Sutera dengan PenggerakMotor Listrik. Makassar: Politeknik Negeri Ujung Pandang.

[4] Sularso dan Kiyokatsu Suga. 1983. Dasar Perancangan dan Pemilihan Elemen Mesin. Jakarta: PT. Pradnya Paramita.

[5] Shigley, Joseph E. 1996, Perencanaan Teknik Mesin. Jakarta: Erlangga 